\title{
Practice Analysis of Using Sports Appreciation Teaching Mode in the Teaching of College Physical Education Theory
}

\author{
Qiang Luo \\ Xi'an International University, Xi'an, 710077, China
}

Keywords: Physical education theory teaching, Sports appreciation teaching, Practical analysis; University

\begin{abstract}
With the reform of College Physical Education in our country, the teaching of physical education in colleges is faced with a new type of reform. In order to be able to reach the teaching objective of college physical education, the new teaching mode is needed in the course of the traditional physical education theory course. And the application of sports appreciation teaching is not only to improve the traditional teaching mode, but also to bring new vitality to the sports class, so the sports appreciation teaching in college physical education theory teaching has irreplaceable role.
\end{abstract}

\section{Introduction}

The wide application of modern educational technology not only change the traditional education mode, but also change the teaching ideas of many courses at present. The teaching of physical education theory in Colleges and universities is carried out in rainy days, but through the implementation of sports appreciation teaching method to stimulate students to learn sports skills of the inner needs, so as have a more intense interest in sports, can promote students' comprehensive development [1].

\section{The existing problems in the teaching of physical education theory in Colleges and Universities}

The sports theory course is in the important position in the University's physical education teaching, is the important process impart the physical education foundation knowledge to the student, let the university students to sports in Science way. but, because of the long-term impact of all aspects, the sports theory in many colleges and universities often stay in the past teaching mode, the teaching process has a large drawbacks, the specific problems are as follows:

\section{The concept of college physical education is backward}

At present, in China's colleges and universities in the actual teaching process, teachers cannot get rid of the backward sports theory teaching ideas, not carry out teaching innovation, so the teacher of physical education in sports theory teaching process often make use of monotonous, boring teaching methods, let the students lose the learning interest in sports, the sports theory knowledge can't spread in student groups, which makes the physical education curriculum progress slow.

\section{Backward teaching mode}

In the teaching mode of physical education in Colleges and universities, because of many factors, many backward teaching mode is still existence, There are three points: First, the physical education teachers pay attention to the immediate interests, paid no attention to students' learning initiative, only pay attention to the particular issues, the overall teaching of physical education in Colleges and Universities is lack of systematic and normative;

\section{A Single physical education teaching content}

In college physical education, the important content of teaching includes two parts, which are the theoretical part and the practical part. Because of the influence of many objective factors, such as weather factor and class factor, make the relevant theoretical system cannot be a good 
communication, students cannot set up the system of sports theory related concepts in mind; In the practice teaching content, because of the characteristics of the students and the constraints of the school limit conditions, a lot of physical education practice teaching cannot be achieved. These objective factors lead to a single physical education content.

\section{The function of Sports Appreciation Teaching}

\section{Strengthen students' physical education knowledge and cultural quality}

Physical education is not only to make the body exercise, improve people's physical, but more important is to stress the peace, coordination of the body and heart. In the past the traditional physical education teaching, the university teachers and students often only pay attention to the physical training, and neglect the training of the students' cultural knowledge. So the sports appreciation teaching form, can let the college students understand and master more knowledge of sports, make their own sports professional knowledge and skills to improve, expand their view, and to understand the real connotation of sports culture.

\section{Improving students' learning interest and efficiency}

Interest is the best teacher, so if students are interested in sports theory courses, then he will put more strength, so that the overall effect of the physical education curriculum is better. Because in the traditional physical education theory teaching method, the students cannot produce enough interest, the teaching effect is unsatisfactory. If using the appreciate teaching form ,so Abstract knowledge become Visual, makes students more interested, and Stimulate students' interest in learning related knowledge..

\section{To promote physical education teachers to improve their teaching quality}

In the process of sports teaching, the most important is to sports training, so this has led to the sports theory teaching has been a relatively weak link [3]. the sports appreciation teaching form is a relatively new teaching mode, so the physical education teachers should keep pace with the times, do a good job in the curriculum design, only physical education teachers to improve their own quality, master more advanced teaching methods, teacher will be able to keep up with the development of the times.

\section{Improving students' innovation ability}

The Appreciation teaching form will allow students through a positive way to get knowledge. So in a certain sense, sports appreciation is a creative activities, which requires students to understand the relevant knowledge from the heart, and to understand the social content, through the students' own thinking to enhance the understanding of the relevant knowledge.

\section{The teaching design of Sports Appreciation Teaching}

The practice of physical education in Colleges and universities is the appreciation of the relevant sports and the form of the multimedia projection or the scene. And Make the students feel the related concept

\section{The teaching goal of sports appreciation}

Through the time of sports appreciation teaching, can effectively spread the relevant sports theory knowledge to the students, it is beneficial for students to broaden their horizons, stimulate their intrinsic interest, and through the interest of the students to develop a passion for sports related activities, so as to get the body healthy development. 


\section{The teaching content of sports appreciation}

The teaching content of sports appreciation is that in the teaching of physical education theory, everything is carried out related sports, such as sports photography, competitions, performances, awards and other forms, teachers should be based on the actual teaching needs, to select the relevant materials, the relevant communication.

\section{Teaching organization form of sports appreciation}

Teaching form of physical education theory in Colleges and universities has two forms, which are direct and indirect. Direct appreciation is that teachers guide students to the stage of the competition, through the competition, can let the students and sports integrated, through the scene of the competition atmosphere, to improve the students' understanding. Indirect appreciation is that through the form of multimedia teaching, such as television, radio, newspapers, multimedia and other ways, this is the most important form of sports appreciation teaching, so that the students can arrange to watch the large sporting events, and then achieve the implementation of the relevant theoretical knowledge.

\section{Teaching method of sports appreciation}

In Colleges and universities, Physical education teachers should carry out appreciate Teaching based on the contents and targets of teaching. First, teachers be done in the preparatory work for the course, take a comprehensive preparation for the sports appreciation teaching and the relevant material. At the beginning of sports appreciation course, the teacher should explain and guide the related theoretical knowledge, students can have the purpose of learning, clear the core of knowledge; secondly, teachers should explain the related knowledge in multimedia projection process. Finally, the course will be the end, to answer the students' questions, so that students can really understand the relevant knowledge of physical education.

\section{The practical performance of the teaching mode of physical education in the College Physical Education Theory Course}

\section{Strengthen the combination of theory and Practice}

In the teaching process of physical education in Colleges and universities, only through the language is impossible to achieve the relevant teaching objectives. Before the theory course, physical education teachers should do a good job in the course preparation, through TV or ppt and other advanced means, display the knowledge of sports technology.

This is not a traditional boring knowledge explanation, Classroom atmosphere has changed, and the learning enthusiasm of the students is also greatly improved. Physical education teachers can combine the theoretical knowledge and the sports appreciation teaching, which can better display the relevant technical action, making the teaching objectives better. So, if you want to really change the existing problems, In the process of teaching and learning, the theory and practice can be effectively combined.

\section{To strengthen the application of the news report of the related competition}

The teachers should make full use of the sports news of the related events, so as to make the teaching objectives to be implemented [5]. China has recently won the bid to host the Olympic Games, Therefore, in the teaching of physical education theory, the application of the related news can make the students have a better understanding of the related sports and improve their sense of patriotism. For example, in the professional knowledge of Football Course, the teacher can start with the latest news reports on football to explain the relevant professional knowledge and rules of football. This not only improves students' learning interest in football, but also can make them better grasp the relevant knowledge. 


\section{Strengthen the influence of sports stars}

College physical education teachers should start from the students' reality, according to the psychological characteristics of the students' growth, most of the college students will have their own sports stars, so the sports star will play a role in the behavior of students. Based on this, the college physical education teachers can use the halo effect of sports stars, so that the sports teaching mode can be more widely used.

If college students in the course of physical education, see their idols, then their hearts will be excited, and has a greater interest in the study of sports related knowledge. For example, in the course of swimming theory, physical education teachers can use Sports appreciation teaching, to show Sun Yang in the Olympic Games get a gold medal for china, so not only improve the students' national pride, but also to improve the effectiveness of the teaching class.

\section{Strengthen the combination of theoretical knowledge and physical health}

In the practice of physical education in Colleges and universities, if we want to effectively implement the relevant teaching objectives, then not only should improve the students to grasp the relevant theoretical knowledge, but also should improve the development of students' physical health. Therefore, the Sports appreciation teaching should combine the education of theoretical knowledge and the students' physical quality. But there is a certain difficulty to carry out technical action training in the classroom, so. The physical education teachers should use the form of digital media to decompose the complex action for the students, so that they can exercise in their spare time, which make the physical education theory course and the students' physical training Combine together, so as to realize the teaching effect of physical theory.

\section{Concluding remarks}

In the course of college physical education theory course, the students are very difficult to produce because of the boring of theory knowledge. So, in order to improve the students' enthusiasm for sports related knowledge learning, Sports appreciation teaching should be used for to strengthen students' mastery of the theory of physical education, to improve their own quality, and get the full development.

\section{References}

[1] Wang Jichao The practical analysis of appreciation of Sports Appreciation Teaching in the university sports theory class teaching. Science Herald, 2014 (11): 211-211.

[2] fan Yong. the necessity and feasibility of using Sports Appreciation Course in the university sports theory class teaching. Technology information, 2012 (34): 635

[3] Liu Hong. The practice analysis of using Sports Appreciation Course in college physical education theory course. Oriental Education, 2014 (4): 11-11,12.

[4] Qiao Jinyu Analysis of the network course of sports appreciation in Colleges and Universities. Electronic commerce, 2015 (7): 78-78,96.

[5] Ye Ming, Zhang Weiwen. Promote sports appreciation build a campus sports culture soft strength. Education and teaching forum, 2012, (23): 79-80. 